\title{
Effect of heat inputs on microstructure and mechanical properties in CGHAZ of BWELDY960Q steel
}

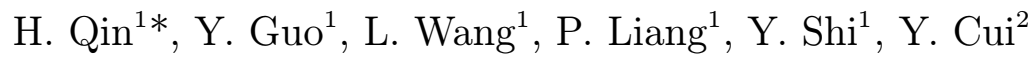 \\ ${ }^{1}$ School of Mechanical Engineering, Liaoning Shihua University, Fushun 113001, P. R. China \\ ${ }^{2}$ Fushun Petrochemical Company Petroleum Third Factory, Liaoning Fushun 113001, P. R. China
}

Received 29 January 2019, received in revised form 7 April 2019, accepted 11 June 2019

\begin{abstract}
The Gleeble 1500 test machine was used to simulate the single-pass welding thermal cycle of BWELDY960Q steel under different heat input conditions. In this paper, microstructure observation and mechanical properties of BWELDY960Q steel specimens in coarse grain heat affected zone (CGHAZ) under different heat input conditions were investigated. The results show that under different heat input conditions, the microstructure of CGHAZ is lath martensite, granular bainite, or M-A constituent. As heat input increases, the number and size of the M-A constituent increase accordingly, and the microstructure gradually changes from lath martensite to granular bainite. Meanwhile, compared with the previous samples, the CGHAZ austenite grain diameter increases, and the grain size scale decreases. Furthermore, the value of the CGHAZ impact absorbing energy increases at first but then decreases, while microhardness monotonously decreases. At $-20^{\circ} \mathrm{C}$ compared with the base metal, the impact absorbing the energy of CGHAZ is significantly reduced, and embrittlement occurs.
\end{abstract}

K e y w o r d s: BWELDY960Q steel, heat inputs, coarse grain heat affected zone, microstructure, mechanical properties

\section{Introduction}

Low-alloy high-strength steel possesses excellent performance and remarkable economic benefits and is widely used in welded structures. To improve production efficiency and save cost, the welding structure design is developing in the direction of high parameters, such as lightweight and large scale [1-5]. Welding is a key technical problem affecting the application of low-alloy high-strength steel. In the welding process, heat input is an important process parameter, which has a significant impact on the microstructure and properties in the welding heat-affected zone of low-alloy high-strength steel [6-10]. After the thermal welding cycle, CGHAZ is in a superheated state during the welding process, and the grain is severely rough and brittle, resulting in a weak area of the welded joint occurring in CGHAZ. Therefore, it is necessary to study the microstructure and properties of highstrength steel CGHAZ. In this field, Ma investigated the effect of the CGHAZ welded Ti-Nb micro-alloy steels on the microstructure under low heat input with $\mathrm{C}$ concentration varied from 0.028 to 0.058 wt. $\%$. It was found that the CGHAZ microstructure exhibited a systematic response to $\mathrm{C}$ content variation. The variation leads to the increase of temperature for $\mathrm{NbC}$ and coarser $(\mathrm{Ti}, \mathrm{Nb}) \mathrm{N}-\mathrm{Nb}(\mathrm{C}, \mathrm{N})$ precipitation, but finer delayed strain-induced $\mathrm{NbC}$ in the high carbon steel than in the low carbon steel [11]. Li investigated the effect of second peak temperature on microstructure feature of the subcritical (SC), intercritical (IC), supercritical (SCR), and unaltered (UA) reheated CGHAZ during in-service welding. It was found that low heat input and accelerated cooling would lead to the smaller grain size in reheated CGHAZ, and the brittle microphases were eliminated or minimized [12].

BWELDY960Q steel is a low-alloy high-strength welded structural steel, known for its high strength and good low-temperature impact toughness. It is often used in the fields of engineering machinery, mining, port, and hydropower. The single pass welding thermal cycle of BWELDY960Q steel was simulated by

*Corresponding author: e-mail address: huaq2008@163.com 
Table 1. Chemical composition of BWELDY960Q steel in this study (mass\%)

\begin{tabular}{lccccccccccccc}
\hline Steel & $\mathrm{C}$ & $\mathrm{Si}$ & $\mathrm{Mn}$ & $\mathrm{S}$ & $\mathrm{P}$ & $\mathrm{Cr}$ & $\mathrm{Ni}$ & $\mathrm{Mo}$ & $\mathrm{Nb}$ & $\mathrm{V}$ & $\mathrm{Ti}$ & $\mathrm{B}$ \\
\hline BWELDY960 & 0.18 & 0.50 & 1.60 & 0.01 & 0.02 & 0.08 & 1.00 & 0.60 & 0.05 & 0.05 & 0.03 & 0.05 \\
\hline
\end{tabular}

Table 2. Mechanical properties of BWELDY960Q in this study

\begin{tabular}{lcccc}
\hline Steel & $R \mathrm{p} 0.2(\mathrm{MPa})$ & $R \mathrm{~m}(\mathrm{MPa})$ & $\mathrm{A}(\%)$ & $\mathrm{Akv}(\mathrm{J}),-20^{\circ} \mathrm{C}$ \\
\hline BWELDY960Q & 960 & 980 & 12 & 102 \\
\hline
\end{tabular}

Table 3. Thermal cycle parameters of CGHAZ under different heat inputs

\begin{tabular}{ccccc}
\hline $\begin{array}{c}\text { Peak temperature, } T_{\mathrm{P} 1} \\
\left({ }^{\circ} \mathrm{C}\right)\end{array}$ & $\begin{array}{c}\text { Heating rate, } \omega_{\mathrm{H}} \\
\left({ }^{\circ} \mathrm{C} \mathrm{s}^{-1}\right)\end{array}$ & $\begin{array}{c}\text { Peak temperature hold time, } t_{\mathrm{H}} \\
(\mathrm{s})\end{array}$ & $\begin{array}{c}\text { Heat input, } q \\
\left(\mathrm{~kJ} \mathrm{~cm}^{-1}\right)\end{array}$ & $\begin{array}{c}\text { Cooling time, } t_{8 / 5} \\
(\mathrm{~s})\end{array}$ \\
\hline 1320 & 103 & 2 & 10 & 13 \\
1320 & 103 & 2 & 20 & 27 \\
1320 & 103 & 2 & 30 & 50 \\
1320 & 103 & 2 & 40 & 70 \\
\hline
\end{tabular}

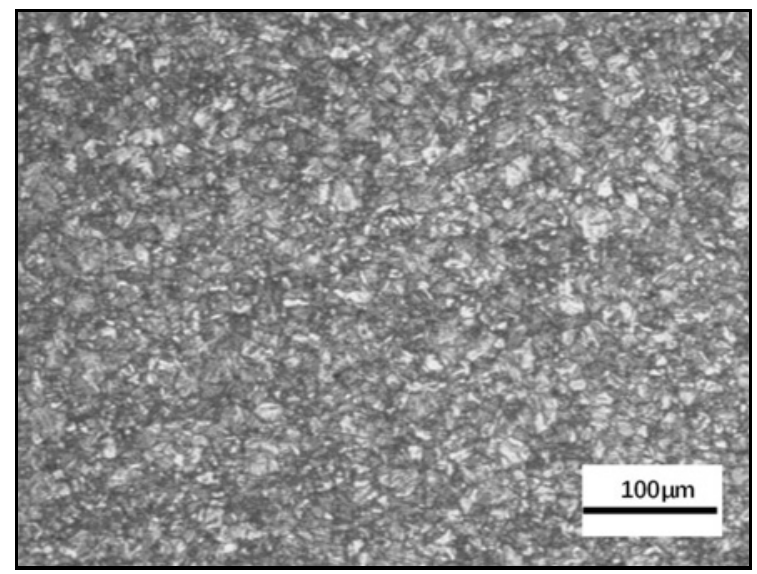

Fig. 1. The microstructure of BWELDY960Q steel.

welding thermal simulation technology. The variation of microstructure and properties of CGHAZ under different heat input were studied, which provided a basis for formulating reasonable welding process and engineering application.

\section{Experimental}

\subsection{Material and test preparation}

The test used BWELDY960Q steel as experimental steel and the microstructure of the base metal was tempered sorbite. The thickness of the plate was $10.04 \mathrm{~mm}$ in the quenching supply state. The microstructure was performed by a Leica QM500 optical microscope, as shown in Fig. 1. Chemical composition and mechanical properties are shown in Tables 1 and 2 . The critical phase transition temperatures $A_{\mathrm{C} 1}, A_{\mathrm{C} 3}$ of BWELDY960Q steel are 725 and $876{ }^{\circ} \mathrm{C}$, respectively.

Thermal simulation test was carried out using a Gleeble 1500 simulation test machine, and thermal simulation samples were taken in the direction of parallel steel plate rolling. The sample size was $90 \mathrm{~mm} \times 10 \mathrm{~mm} \times 10 \mathrm{~mm}$, taken from the weld CGHAZ of the material, and the peak temperature $\left(T_{\mathrm{p} 1}\right)$ was $1320^{\circ} \mathrm{C}$. The heat input was $10,20,30$, and $40 \mathrm{~kJ} \mathrm{~cm}^{-1}$, and the parameters of the thermal welding cycle are shown in Table 3 . The actual welded joint of BWELDY960Q steel was obtained by MAG welding method. Panasonic VD-500GL3 full digital pulse welding machine was used to carry out welding. The heat input was $10 \mathrm{~kJ} \mathrm{~cm}^{-1}$, the test plate thickness was $10 \mathrm{~mm}$, the joint was in the form of $\mathrm{V}$-groove flat butt welding, the angle of the groove is $60^{\circ}$, the blunt edge is $2 \mathrm{~mm}$, the gap was $2 \mathrm{~mm}$, and $80 \% \mathrm{Ar}+20 \% \mathrm{CO}_{2}$ mixed gas was used as the welding shielding gas, the shielding gas flow rate was $16-17 \mathrm{~L} \mathrm{~min}^{-1}$ for multi-layer multi-pass welding.

The thermal simulation samples under different heat input conditions were processed into standard impact specimens of $10 \mathrm{~mm} \times 10 \mathrm{~mm} \times 55 \mathrm{~mm}$. The V-notches were machined at the thermocouple spot welding, and the impact test at $-20^{\circ} \mathrm{C}$ was performed using a JB-30B impact tester. The average value of three samples of each group was obtained. The metallographic sample was taken from the cross section of the thermal simulation sample to observe microstructure. The thermal simulation sample was cut into 

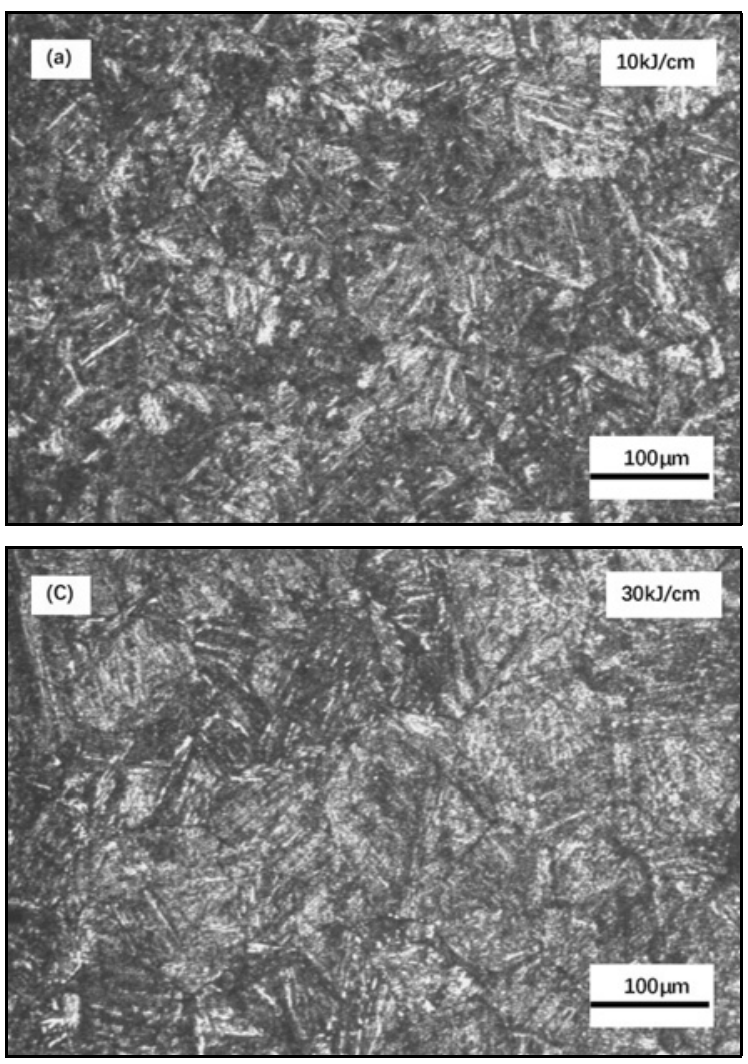
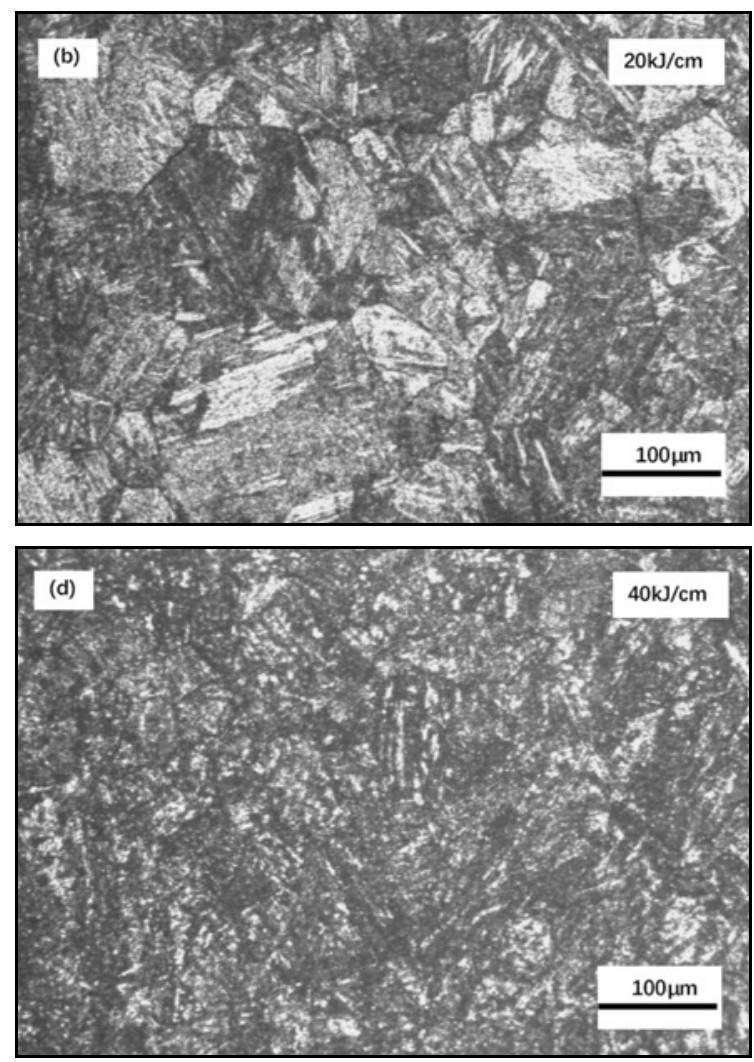

Fig. 2. The optical microstructure of CGHAZ under different heat inputs: $10 \mathrm{~kJ} \mathrm{~cm}^{-1}$ (a), $20 \mathrm{~kJ} \mathrm{~cm}^{-1}(\mathrm{~b}), 30 \mathrm{~kJ} \mathrm{~cm}^{-1}$ (c), and $40 \mathrm{~kJ} \mathrm{~cm}^{-1}(\mathrm{~d})$.

$1 \mathrm{~mm}$ thin slices by wire cutting, and the TEM samples were prepared by mechanical thinning and electrolytic double spraying.

\section{Results and discussion}

\subsection{CGHAZ microstructure}

The optical microstructure of CGHAZ of BWELDY960Q steel under different heat input conditions is shown in Fig. 2, and the SEM microscopic morphology is presented in Fig. 3. After the simulated welding thermal cycle, the microstructure of CGHAZ is lath martensite, granular bainite, or M-A constituent. The morphology, size, and distribution of CGHAZ are different due to different heat inputs. Under the lower heat input $\left(10 \mathrm{~kJ} \mathrm{~cm}^{-1}\right)$ and a faster cooling rate, the microstructure of CGHAZ is coarser lath martensite. It can be seen in Figs. 2a and 3a that at the austenite grain boundaries, parallel slats grow from the grain boundaries into the crystal and slender slats stretched in the same orientation form a wide slat bundle. When the heat input amount reaches $20 \mathrm{~kJ} \mathrm{~cm}^{-1}$ and the cooling rate decelerates, the austenite grains sharply grow up and the number of lath martensite decreases, causing the microstruc- ture transforms into a mixture of martensite and bainite [13-16]. A little M-A constituent appears in the microstructure, but the M-A constituent size is still small, as shown in Figs. 2b, 3 b.

When the heat input further increases and corresponding cooling time $\left(t_{8 / 5}\right)$ prolongs, the bainite in the structure is in a transition state, and the lath features disappear gradually. The microstructure of CGHAZ is transformed into a mixture of granular bainite and M-A constituent, distributed in strips or blocks on the matrix of ferrite base with the size and amount rising gradually, as shown in Figs. 2d, 3d. The formation of M-A constituent preferring at a lower cooling rate is due to the increase of carbon content in austenite. When the non-equilibrium structure of CGHAZ is reheated, because the non-equilibrium structure has a specific orientation, the carbon is directionally diffused to form new austenite with obvious direction and forms a carbon-rich region. During the subsequent cooling process, carbon-rich austenite transforms to M-A constituent [17-20]. As the heat input increases, the cooling becomes slower, which is beneficial to the precipitation and aggregation of M-A constituent [21-24].

EDS analysis (Fig. 4) was performed on the 1 point of the M-A constituent and the 2 points near the matrix in Fig. 3d. By analysis, it is found that 

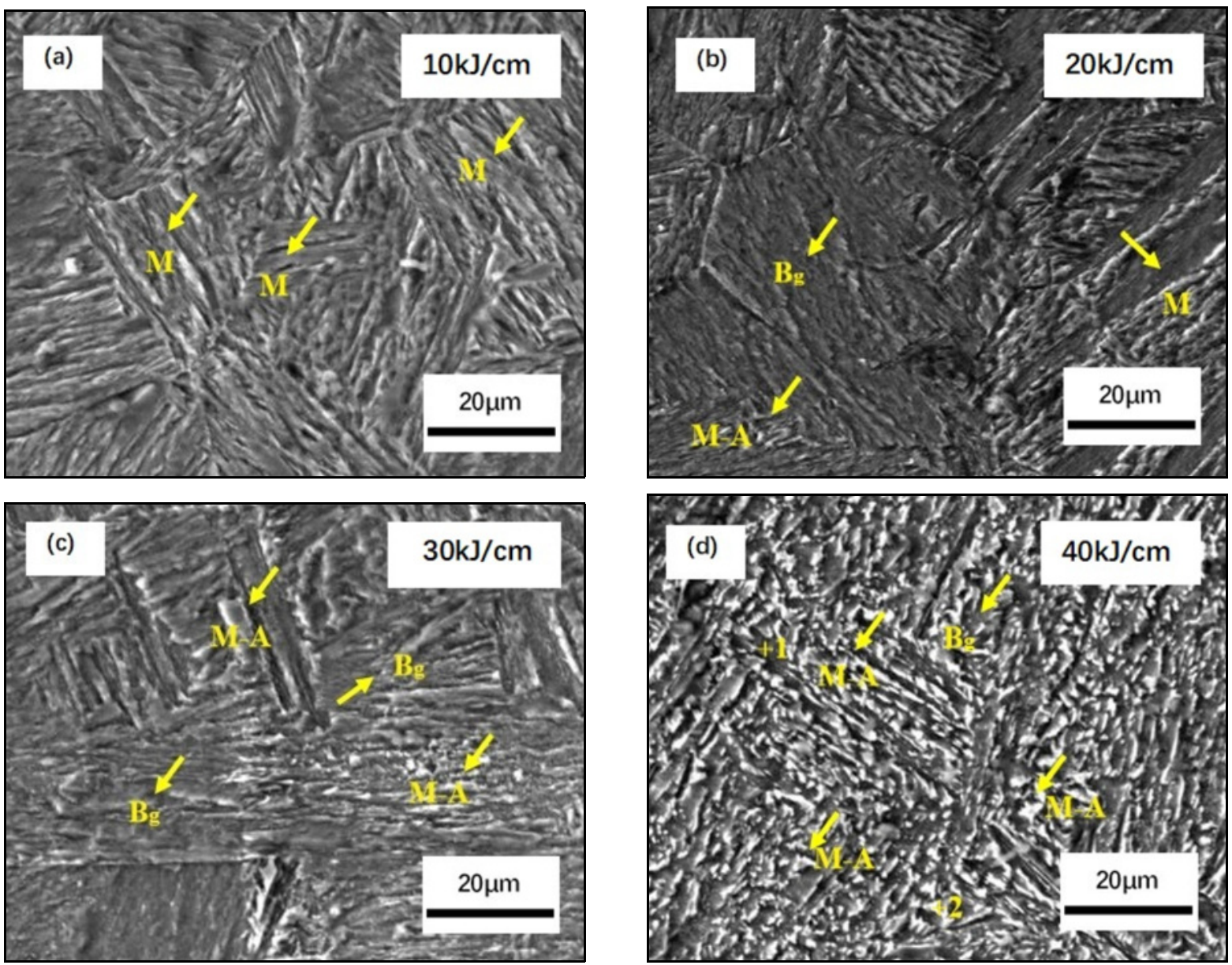

Fig. 3. SEM microstructure of CGHAZ under different heat inputs: $10 \mathrm{~kJ} \mathrm{~cm}^{-1}$ (a), $20 \mathrm{~kJ} \mathrm{~cm}^{-1}$ (b), $30 \mathrm{~kJ} \mathrm{~cm}^{-1}$ (c), and $40 \mathrm{~kJ} \mathrm{~cm}^{-1}(\mathrm{~d})$.
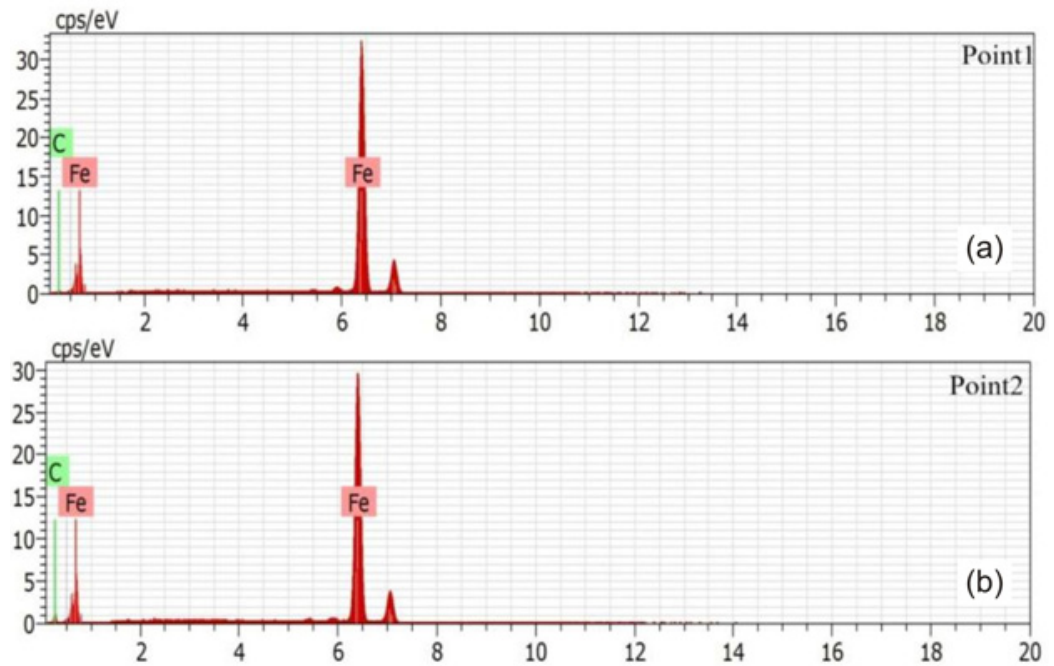

Fig. 4. Energy dispersive spectrometer analysis of M-A constituent (a) and base metal (b).

the carbon content at points 1 and 2 is $14.60 \%$ and $5.28 \%$, respectively. The carbon content of the M-A constituent is significantly higher than that of the matrix. When the experimental steel CGHAZ is in the mid-temperature upper bainite transformation zone, the cooling rate is small. So carbon is diffused from the $\alpha / \gamma$-phase boundary to $\gamma$, and the island-shaped M-A constituent surrounded by ferrite is en- 

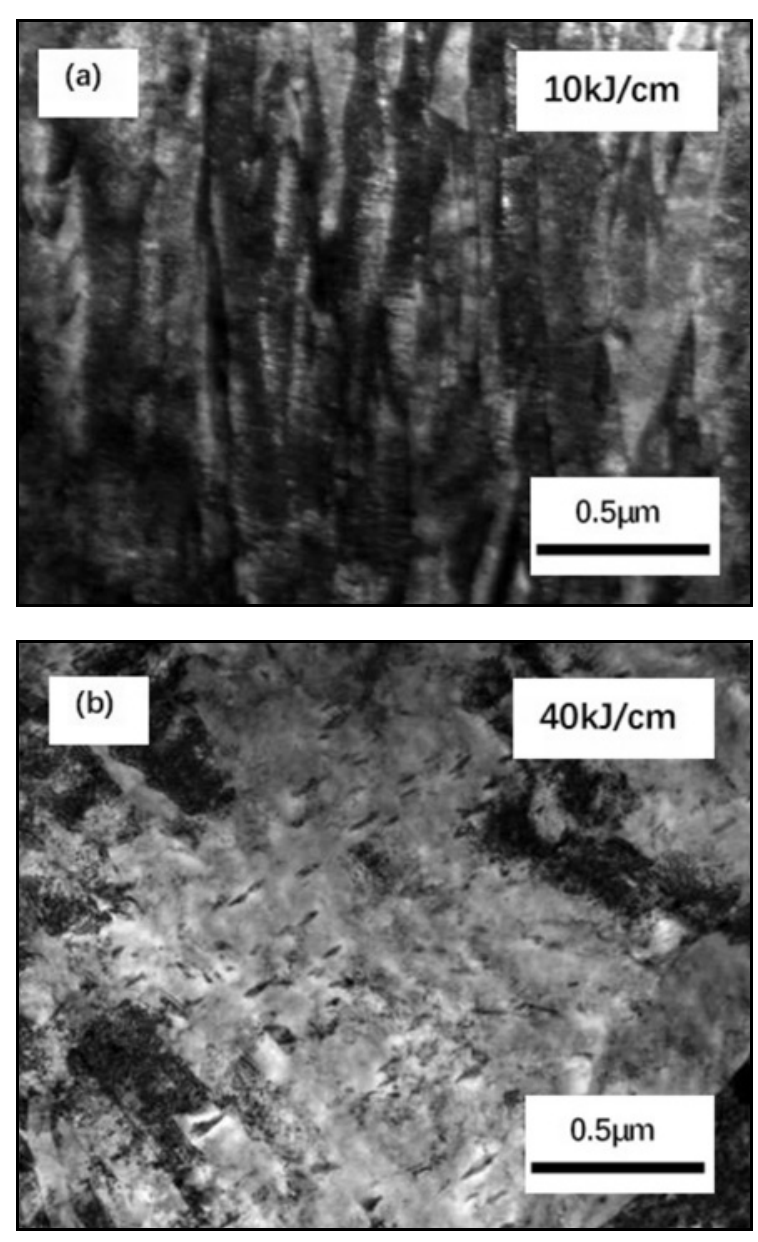

Fig. 5. TEM morphology of CGHAZ: $10 \mathrm{~kJ} \mathrm{~cm}^{-1}$ (a) and $40 \mathrm{~kJ} \mathrm{~cm}^{-1}(\mathrm{~b})$.

riched with a large number of carbon atoms, resulting in the higher carbon content of M-A constituent.

Figures 5a,b show the structural characteristics of CGHAZ at heat input rates of 10 and $40 \mathrm{~kJ} \mathrm{~cm}^{-1}$. At lower heat input $\left(10 \mathrm{~kJ} \mathrm{~cm}^{-1}\right)$, it is observed that the martensite microstructure has obvious slab morphology and its structure is mainly dislocation with a local lattice distortion region around it. When the heat input reaches $40 \mathrm{~kJ} \mathrm{~cm}^{-1}$, the microstructure of CGHAZ is granular bainite and M-A constituent, which is distributed in strips or blocks on the original austenite grain and grain boundaries with the maximum size reaching up to $1.6 \mu \mathrm{m}$, as shown in Fig. 5b.

\subsection{CGHAZ grain size analysis}

The relations of CGHAZ austenite grain size scale and the average grain diameter, as well as heat input, are presented in Fig. 6. It is found that the heat input significantly affects the size of the CGHAZ grains, and under different heat inputs, after the heat cy-

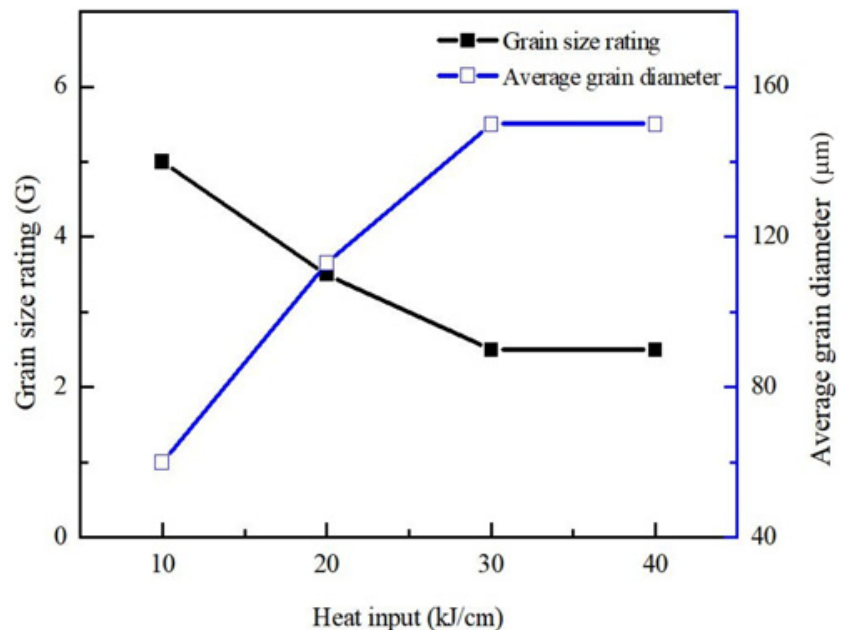

Fig. 6. Austenite grain size rating and average grain diameter of CGHAZ under different heat inputs.

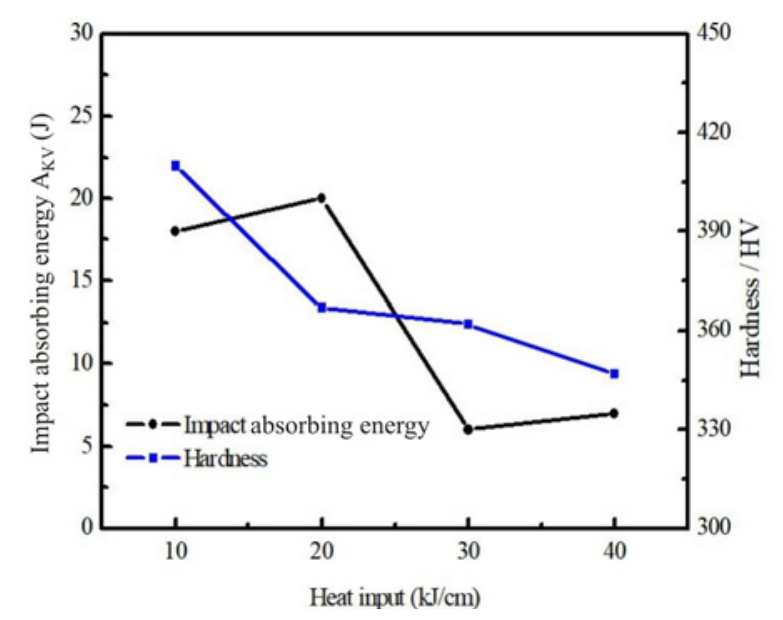

Fig. 7. Properties of CGHAZ under different heat inputs.

cle of welding, the CGHAZ austenite grains diameter changes greatly. When the heat input increases from 10 to $20 \mathrm{~kJ} \mathrm{~cm}^{-1}$, the grain size of CGHAZ increases sharply, becoming twice approximately. However, as the heat input increases from 20 to $30 \mathrm{~kJ} \mathrm{~cm}^{-1}$, the rising rate of CGHAZ grains becomes slowly. However, when the heat input increases to $40 \mathrm{~kJ} \mathrm{~cm}^{-1}$, the austenite grain size tends to be stable. The increase of heat input causes the small particles pinned at the austenite grain boundary to dissolve, and the pinning effect cannot be achieved, also, the atomic diffusion velocity at the austenite grain boundary increases, which is beneficial to austenite grain growth [25-28].

\subsection{CGHAZ mechanical properties}

The effect of different heat inputs on the mechanical properties of CGHAZ is shown in Fig. 7. At 
$-20^{\circ} \mathrm{C}$, in comparison with the base metal, the impact absorbing the energy of CGHAZ is greatly reduced, which means that the CGHAZ of BWELDY960Q steel is embrittled. The CGHAZ is the weakest zone of the welded joint, and its impact toughness mainly depends on the selection of the heat input. As the heat input increases, the value of the impact absorbing energy increases at first and then decreases. After the experimental steel experienced a thermal cycle with a peak temperature of $1320^{\circ} \mathrm{C}$, microstructure has undergone major changes. When the heat input is low $\left(10 \mathrm{~kJ} \mathrm{~cm}^{-1}\right)$, as shown in Fig. 3a, the CGHAZ structure is mainly lath martensite, the slats are thin and straight, while the cracks are easy to expand between the martensite laths; all of them lead to toughness decrease. When the heat input is $20 \mathrm{~kJ} \mathrm{~cm}^{-1}$, the value of CGHAZ impact absorption energy is $20 \mathrm{~J}$, which reaches the maximum value. Although the austenite grains have grown significantly, the microstructure is a mixed structure of lath martensite and granular bainite, a small quantity of M-A constituent with small size is distributed on the ferrite matrix, as shown in Fig. 3b, so that the impact toughness is slightly improved. As the heat input further increased to $30 \mathrm{~kJ} \mathrm{~cm}^{-1}$, the cooling time is prolonged, which provides favorable conditions for the formation of M-A constituent. The bright white M-A constituent with various shapes, such as long strips, rods and islands, is distributed along grain boundaries and grain interior. Also, the number of M-A increases significantly, and the size of the M-A constituent becomes larger, which becomes the main channel for crack propagation. Shown in Figs. 3c,d, the impact toughness of CGHAZ drops sharply [29-31].

When the welding heat input increases from 10 to $40 \mathrm{~kJ} \mathrm{~cm}^{-1}$ and the cooling rate becomes slower, the microhardness of CGHAZ shows a monotonous downward trend. When the welding heat input is small, that is, the cooling speed is fast, the lath martensite microstructure is mainly formed. The high-density dislocation of the lath martensite acts as a pinning effect, which increases the resistance of the dislocation motion and limits the slip of the dislocation, leading to higher hardness $[32,33]$. When the heat input in-
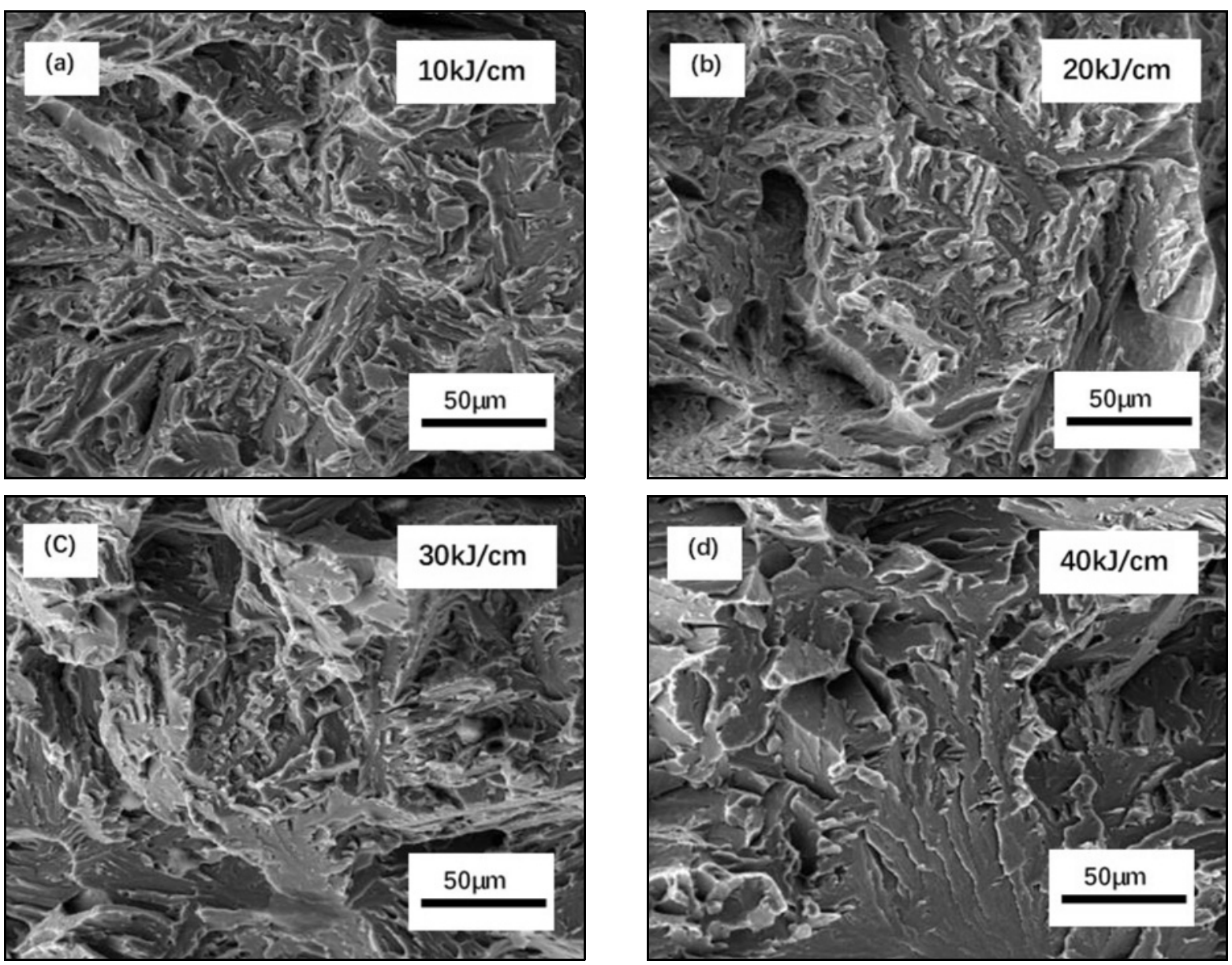

Fig. 8. Micro-fracture feature of CGHAZ under different heat inputs: $10 \mathrm{~kJ} \mathrm{~cm}^{-1}$ (a), $20 \mathrm{~kJ} \mathrm{~cm}^{-1}$ (b), $30 \mathrm{~kJ} \mathrm{~cm}^{-1}$ (c), and $40 \mathrm{~kJ} \mathrm{~cm}^{-1}$ (d). 
creases, granular bainite gradually forms in the structure. Due to the high formation temperature of the granular bainite, the ferrite base strip is coarser, the carbon supersaturation and the dislocation density are much lower, which leads to lower hardness value [34, $35]$.

The effect of the microstructure, grain size, number of M-A constituent, and morphology distribution of BWELDY960Q steel CGHAZ on toughness is very important. There are two main reasons for the CGHAZ embrittlement. On the one hand, the CGHAZ grains are coarse, and the peak temperature far exceeds the critical phase transition temperature $A_{\mathrm{C} 3}$. After rapidly heating and cooling, the grains obtained in the microstructure are coarse, the number of grain boundaries is small, and the crack propagation resistance is lowered, which results in a significant decrease in impact toughness. On the other hand, as the heat input increases, both the size and number of M-A constituent in the microstructure are increased, and microcracks firstly formed at the interface between the M-A constituent and the ferrite matrix. The stripy or large M-A constituent provide a channel for the formation and expansion of cracks so that toughness sharply decreases. It means that larger size of M-A constituent has a significant hazard to toughness.

Scanning electron microscopy is used to observe the microscopic morphology of the impact fracture of CGHAZ specimens at $-20^{\circ} \mathrm{C}$ under different heat input conditions, as shown in Fig. 8. It can be seen from Fig. 8 that under the different heat input conditions, the sample has almost no macro-plastic deformation before fracture, and the microscopic morphology has cleavage fracture. The original coarse austenite grain size grade of CGHAZ is lower, the size of the cleavage plane becomes more extensive, the number of grain boundaries decreases and the straight river pattern extends from the cleavage cracking to the surrounding, the crack expansion forms a fracture step when it encounters an obstruction. Also, the M-A constituent can promote the formation of cracks as a potential crack source, the crack is easy to form and expand under the impact load, resulting in lower value of CGHAZ impact work, poor toughness, and impact fracture is cleavage fracture.

\subsection{Comparative analysis}

The heat input to BWELDY960Q steel during the MAG welding process is the heat generated by the arc. When the adjacent weld site is subjected to high arc heat, the temperature of the heat influence is a gradient, which leads to the continuity and gradient microstructure of the heat affected zone. The thermal simulation takes longer to heat up to the peak temperature than the practical welding, and the subsequent cooling rate is also slower than that of practical weld-

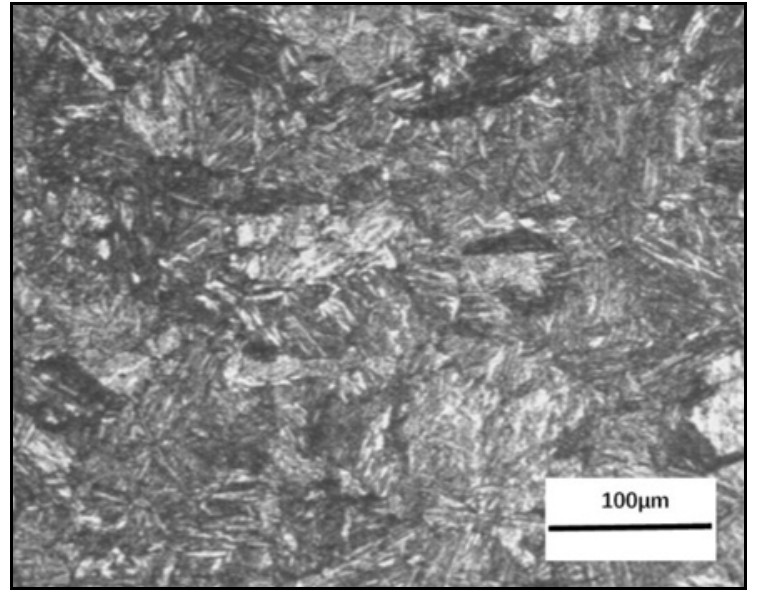

Fig. 9. The microstructure of CGHAZ under practical welding.

ing. The microstructure transformation during heating is the same as the one during cooling, and there is no microstructure gradient to limit the grain growth, so that the grain of the simulated welding CGHAZ is coarser, as shown in Fig. 9. In terms of performance, the hardness of the practical welding CGHAZ is higher than that of thermal simulation CGHAZ under the same heat input condition $\left(10 \mathrm{~kJ} \mathrm{~cm}^{-1}\right)$. Although the microstructure of the thermal simulation CGHAZ is different from the practical welding, the thermal simulation technology can be used to reveal the changes of CGHAZ microstructure performance under different thermal cycles, which has specific significance to promote the welding application of BWELDY960Q high strength steel.

\section{Conclusions}

1. The CGHAZ microstructures are lath martensite, granular bainite or M-A constituent under different heat inputs. As the heat input increases, the microstructure changes from lath martensite to granular bainite, and the number as well as the size of M-A constituent increase.

2. The CGHAZ austenite grains are coarsened after a thermal cycle of welding under different heat inputs. When the heat input amount increases from 10 to $20 \mathrm{~kJ} \mathrm{~cm}^{-1}$, the grains of CGHAZ sharply grow up, and the grain size of CGHAZ at $20 \mathrm{~kJ} \mathrm{~cm}^{-1}$ is about twice that at $10 \mathrm{~kJ} \mathrm{~cm}^{-1}$. Under the different heat input conditions, the sample has almost no macroplastic deformation before fracturing, and the microscopic morphology is cleavage fracture.

3. As the heat input increases, the value of the CGHAZ impact absorbing energy increases first and then decreases, while microhardness monotonously increases. At $-20^{\circ} \mathrm{C}$, the CGHAZ impact absorbing en- 
ergy is significantly decreased, that is, the embrittlement occurs.

4. The grain diameter of the simulated welded CGHAZ is larger than that of the practical welded CGHAZ.

\section{Acknowledgement}

The present research was financially supported by the Science and Technology Research Project of the Department of Education of Liaoning Province (No. L2017LQN021).

\section{References}

[1] Joshi, J. R., Potta, M., Adepu, K., Katta, R. K., Gankidi, M. R.: Trans. Indian. Inst. Met., 70, 2017, p. 69. doi:10.1007/s12666-016-0861-4

[2] Rogne, B. R. S., Thaulow, C., Barnoush, A.: Metall. Mater. Trans. A, 45, 2014, p. 1996. doi:10.1007/s11661-013-2168-y

[3] Dicecco, S., Altenhof, W., Hu, H., Banting, R.: J. Mater. Eng. Perform., 26, 2017, p. 1758. doi:10.1007/s11665-017-2565-2

[4] Jain, D., Isheim, D., Hunter, A. H., Seidman, D. N.: Metall. Mater. Trans. A, 47, 2016, p. 3860. doi:10.1007/s11661-016-3569-5

[5] Roy, S., Patra, S., Neogy, S., Laik, A., Choudhary, S. K., Chakrabarti, D.: Metall. Mater. Trans. A, 43, 2012, p. 1845. doi:10.1007/s11661-011-1045-9

[6] Mortazavi, E., Najafabadi, R. A., Meysami, A.: J. Iron. Steel. Res. Int., 24, 2017, p. 1248. doi:10.1016/S1006-706X(18)30024-4

[7] Shi, M. H., Yuan, X. G., Huang, H. J., Zhang, S.: J. Mater. Eng. Perform., 26, 2017, p. 3160. doi:10.1007/s11665-017-2758-8

[8] Peng, Y., Zhang, Y. J., Zhao, L., Ma, C. Y., Tian, Z. L.: Weld. World, 62, 2018, p. 961. doi:10.1007/s40194-018-0587-5

[9] Amer, A. E., Koo, M. Y., Lee, K. H., Kim, S. H., Hong, S. H.: J. Mater. Sci., 45, 2010, p. 1248. doi:10.1007/s10853-009-4074-7

[10] Yang, H., Wang, X. X., Qu, J. B.: J. Iron. Steel. Res. Int., 21, 2014, p. 787. doi:10.1016/S1006-706X(14)60142-4

[11] Ma, X. P., Li, X. D., Langelier, B., Gault, B., Subramanian, S., Collins, L.: Metall. Mater. Trans. A, 49, 2018, p. 4824. doi:10.1007/s11661-018-4751-8

[12] Li, C. W., Wang, Y., Chen, Y. H.: J. Mater. Sci., 46, 2011, p. 6424. doi:10.1007/s10853-011-5592-7

[13] Zhao, C. Z., Kingkam, W., Ning, L., Zhang, H. X., Li, Z. M.: J. Mater. Eng. Perform., 27, 2018, p. 4129. doi:10.1007/s11665-018-3510-8

[14] Qiao, G. Y., Xiao, F. R., Zhang, X. B., Cao, Y. B., Bo, L.: Trans. Nonferrous. Met. Soc. China, 19, 2009, p. 1395. doi:10.1016/S1003-6326(09)60039-X
[15] Tanguy, B., Luu, T. T., Perrin, G., Pineau, A., Besson, J.: Int. J. Pres. Ves. Pip., 85, 2008, p. 322. doi:10.1016/j.ijpvp.2007.11.001

[16] Zhu, Z. X., Han, J., Li, H. J.: Metall. Mater. Trans. A, 46, 2015, p. 5467. doi:10.1007/s11661-015-3122-y

[17] Spachinger, S. J., Ernst, W., Enzinger, N.: Weld. World, 61, 2017, p. 1117. doi:10.1007/s40194-017-0480-7

[18] Saxena, A., Kumar, V., Datta, R.: J. Mater. Eng. Perform., 20, 2011, p. 1481. doi:10.1007/s11665-010-9780-4

[19] Ma, F. J., Wen, G. H., Tang, P., Xu, G. D., Mei, F., Wang, W. L.: Metall. Mater. Trans. B, 42, 2011, p. 81. doi:10.1007/s11663-010-9454-5

[20] Li, H. P., Jiang, R., He, L. F., Yang, H., Wang, C., Zhang, C. Z.: Acta. Metall. Sin-Engl., 31, 2018, p. 33. doi:10.1007/s40195-017-0594-3

[21] Li, C. W., Wang, Y., Han, T., Han, B., Li, L. Y.: J. Mater. Sci., 46, 2017, p. 727. doi:10.1007/s10853-010-4803-y

[22] Nawrocki, J. G., DuPont, J. N., Marder, A. R., Robino, C. V.: Metall. Mater. Trans. A, 32, 2001, p. 2585. doi:10.1007/s11661-001-0048-3

[23] Wang, Z. F., Shi, M. H., Tang, S., Wang, G. D., Wuhan, J.: Univ. Technol., 32, 2017, p. 1163. doi:10.1007/s11595-017-1726-3

[24] Jafarian, H. R., Borhani, E., Shibata, A., Terada, D., Tsuji, N.: Mater. Sci., 46, 2011, p. 4216. doi:10.1007/s10853-010-5018-y

[25] Kumar, S., Nath, S. K.: Trans. Indian Inst. Met., 70, 2017, p. 239. doi:10.1007/s12666-016-0880-1

[26] Zheng, L., Yuan, Z. X., Song, S. H., Xi, T. H., Wang, Q.: J. Iron. Steel. Res. Int., 19, 2012, p. 73. doi:10.1016/S1006-706X(12)60063-6

[27] Park, D. Y., Amirkhiz, B. S., Gravel, J. P., Wang, Y. Y., Li, L. J., Zavadil, R., Liang, J., Liu, P., He, A. Q., Arafin, M.: Metall. Mater. Trans. A, 48, 2017, p. 3248. doi:10.1007/s11661-017-4100-3

[28] Zhang, L., Kannengiesser, T.: Weld. World, 62, 2018, p. 339. doi:10.1007/s40194-018-0558-X

[29] Li, X. D., Ma, X. P., Subramanian, S. V., Shang, C. J.: Int. J. Fracture, 193, 2015, p. 131. doi:10.1007/s10704-015-0024-3

[30] Zhu, Z. X., Kuzmikova, L., Li, H. J., Barbaro, F.: Metall. Mater. Trans. B, 45, 2014, p. 229. doi:10.1007/s11663-013-0008-5

[31] Terasaki, H., Shintome, Y., Komizo, Y., Ohata, M., Moriguchi, K., Tomio, Y.: Metall. Mater. Trans. A, 46, 2015, p. 2035. doi:10.1007/s11661-015-2817-4

[32] Mohseni, P., Solberg, J. K., Karlsen, M., Akselsen, O. M., Østby, E.: Metall. Mater. Trans. A, 45, 2014, p. 384. doi:10.1007/s11661-013-2110-3

[33] Liu, C. Y., Di, X. J., Chen, C. X., Guo, X. J., Xue, Z. K.: J. Mater. Sci., 50, 2015, p. 5079. doi:10.1007/s10853-015-9060-7

[34] Mohammadijoo, M., Kenny, S., Collins, L., Henein, H., Ivey, D. G.: Metall. Mater. Trans. A, 48, 2017, p. 2247, doi:10.1007/s11661-017-4041-x

[35] Kim, S., Im, Y. R., Lee, S., Lee, H. C., Kim, S. J., Hong, J. H.: Metall. Mater. Trans. A, 35, 2004, p. 2027. doi:10.1007/s11661-004-0151-3 